\title{
Spatial analysis of caries experience in population of teens, adults, and elderly people in the state of São Paulo: data from SB SP 2015
}

Antonio Carlos Pereira ${ }^{a}$, Antonio Carlos Frias ${ }^{b}$, Vladen Vieira ${ }^{c}$, Livia Fernandes Probst ${ }^{a}$, Emilio Prado da Fonseca ${ }^{a}$, Marcelo de Castro Meneghim ${ }^{a}$

\begin{abstract}
OBJECTIVE: Estimate the prevalence and gravity of coronal dental caries for populations of adolescents, adults and elderly people.

METHODS: For the crossing of data of the average DMF rates by Regional Health Directorate (RHD) with the digital cartographical base, municipals were grouped by RHD, and the connection between the two bases was formed by a common code or "primary key" in the TerraView ${ }^{\circledR}$ software program (version 4.2.1)

RESULTS: The distribution of the DMF average for the teen population was the worst for RHD 8, while RHDs 4, 7 and 14 had lower averages. For the adult population, RHDs 4 and 12 presented the lowest DMF averages. On the other hand, RHDs 8, 13, and 16 had the worst results. For the elderly population, the RHD 4 presented the lowest average, and RHD 9 the highest DMF rate for this population.

CONCLUSION: The differences in DMF averages among the RHDs and the populations studied showed that it is necessary to plan different locoregional oral health actions to face the severe clinical state exposed, since its spatial distribution is disparate, with concentrations of cases in certain regions for all age groups studied.
\end{abstract}

Keywords: dental caries; spatial analysis; dental health surveys; DMF index; oral health.

Análise espacial da experiência de cárie em população de adolescentes, adultos e idosos do estado de São Paulo: dados do SB SP 2015

\section{RESUMO}

OBJETIVO: Estimar a prevalência, gravidade e distribuição da cárie dentária na população de adolescentes, adultos e idosos.

METODOLOGIA: Para o cruzamento dos dados foi realizada a ligação entre as duas bases por um código comum ou "chave primária" no software TerraView" (versão 4.2.1).

RESULTADOS: A distribuição da média CPOD para a população adolescente foi pior para a DRS 8, enquanto as DRS 4, 7 e 14 apresentaram as menores médias. Para a população adulta, as DRS 4 e 12 apresentaram as menores médias CPOD. Em contrapartida, as DRS 8, 13 e 16 mostraram os piores resultados. Em relação à população idosa, a DRS 4 apresentou menor média, e a DRS 9 a maior média CPOD para esta população. CONCLUSÃO: As diferentes médias dos CPOD entre as DRS e entre as populações estudadas demonstram a necessidade de planejamento de ações de saúde bucal locorregionais diferentes para o enfrentamento da heterogeneidade encontrada.

Palavras-chave: cárie dentária; inquéritos epidemiológicos; inquéritos de saúde bucal; índice CPO; saúde bucal. a Piracicaba Dental School, UNICAMP, Piracicaba, Brazil

${ }^{b}$ School of Dentistry, USP, São Paulo, Brazil c São Paulo State Secretary of Health, São Paulo, Brazil
Conflict of Interests: The authors state that there no financial and personal conflicts of interest that could have inappropriately influenced their work.

Copyright: (C) 2018 Pereira et al licensee EDIPUCRS.

This work is licensed under a Creative Commons Attribution 4.0 International License. 


\section{INTRODUCTION}

Oral health surveys are cross-sectional studies that provide information on the oral health conditions and dental care needs of a population. They can provide conditions for controlling changes to the levels or patterns of these diseases [1]. In Brazil, the national studies undertaken in 1986, 1996, 2003, and 2010 were determinats for the knowledge of the epidemiologic profile and historic evolution of the main oral health problems in the country, as well as to subsidize the restructuration of the National Oral Health Policy [2-4].

Caries remain the main grievance in public oral health, negatively impacting individuals and communities by causing pain and suffering, compromising mastication and feeding, and reducing quality of life [5-7]. Socioeconomic conditions are distal determinants for the development of this disease, since they modulate exposure to risk and protection factors, as well as access to oral health services [7]. Brazil is one of the most unequal countries in the world, with notably socioeconomic regional disparities that directly reflect the inequality of access to oral health care in analyses of populations and individuals [6].

Currently, geographic space is seen as a set of dynamically interrelated social, economic, cultural, and environmental elements [8]. The way "humanized geographic space" is occupied and used establishes circulation flows of goods and services, with reflections on the health of the social groups $[8,9]$. Thus, the distribution of oral health afflictions can be understood - in other words, a difference in geographic position also represents a difference in social position [8]. The oral epidemiologic studies that use spatial analysis techniques are recent. In Piracicaba, Pereira et al. [9] associated the distribution of dental caries in children with underprivileged neighborhoods.

In light of the above and considering that epidemiologic studies should endorse health practices by subsidizing and orienting political interventions in health through actions of promoting, monitoring, and improving the comprehensiveness of health care, this study aims to estimate the prevalence and gravity of coronal dental caries for populations of 15 to 19 years of age, 35 to 44 , and 65 and up, undertaking a spatial analysis of their distribution in the state of São Paulo. For this purpose, we used data from the São Paulo State Oral Health Survey (SB SP) performed in 2015.

\section{METHODS}

The survey protocol was approved by the Research Ethics Committee of the Piracicaba School of Dentistry (FOP UNICAMP) under the number 094/2015. It is a descriptive cross-sectional study that used data from "SB SP 2015 - São Paulo State Oral Health Survey”. SB SP 2015 was a state survey with representation for six macro regions, representing all of the São Paulo state (city of São Paulo, metropolitan region, and Regional Health Directorates 2 to 17), as shown in Figure 1. The design of the sampling plan was elaborated by cluster in two stages of drawing by name, with probabilities proportional to the population size (PPS), considering the sampling weight and design effect in the respective stages of drawing names.

The age groups used in this study are those recommended by the World Health Organization (WHO) [9], namely: 15 to 19 years of age, 35 to 44 , and 65 and up. The sample size was defined based on the estimated frequency, variability of the problem being investigated, and acceptable margin of error. All these estimates originate from the results of the SB Brazil 2010 study, regarding the city of São Paulo (macro region 1, capital, and São Paulo metropolitan region) and the Southeast countryside (for the remaining macro regions 2 to 6). To calculate the sample size for dental caries, the formula for sample calculation proposed by Silva [10] was used, which considers the average and standard deviation values of the variable being studied.

To evaluate dental caries in the population, we used the DMF (Decay-Missing-Filled) index, recommended by the WHO [11], and verified treatment needs. The root conditions were not evaluated in SB SP 2015. All information on SB SP 2015 is available at http://w2.fop.unicamp.br/ sbsp2015/, including the publication of the final report [12]. First, a table of attributes was assembled with data on the weighted averages of the DMF index by Regional Health Directorate (RHD) [12]. Two census sectors were drawn by city and the minimum $n$ per sector was calculated (except for

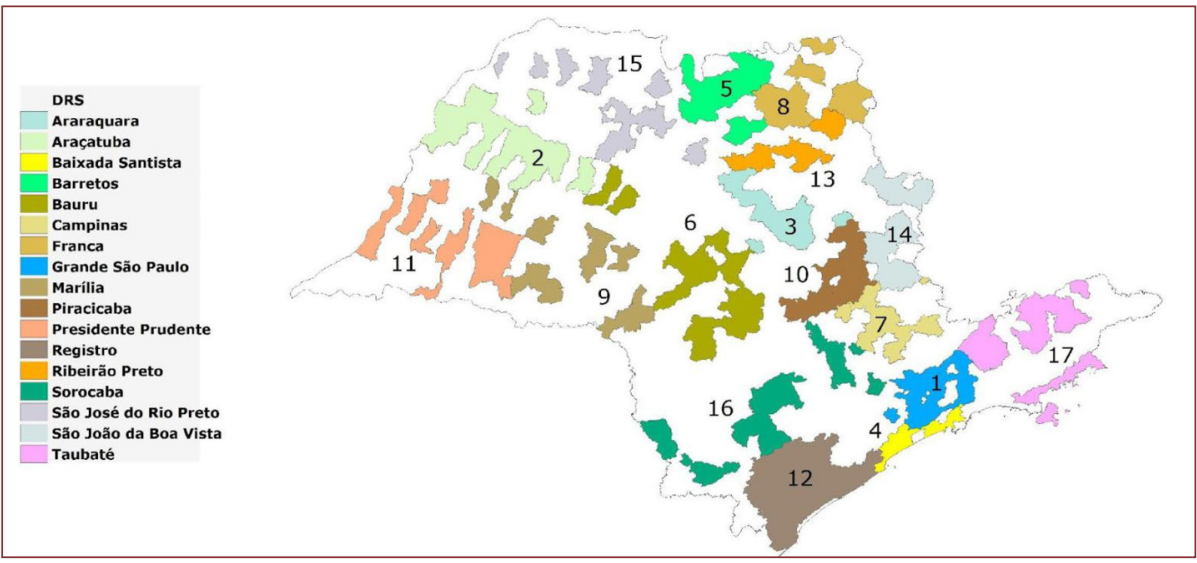

Figure 1. Map of the locations of each RHD of the state of São Paulo. 
the city of São Paulo, where 36 sectors were drawn). As each census sector presents distinct characteristics of population density by age group, all homes occupied were visited and the eligible occupants in the age groups were registered on the enrollment sheet. Then, the residents were examined and interviewed. Those absent and who refused to participate in the study were excluded from the survey.

Next, the data were weighted by calculating the densification rate for each census sector, the number of interviewees/subjects and the rate of no response, these being fundamental for the correction of the analyses, as they generate weights for the weighting process within the sector and in the macro region, as well as for the three age groups: adolescent, adult, and elderly. Finally, the municipals participating in the study were selected from a digital cartographic base of the territory of the state of São Paulo. Then, a file in shapefile format was generated containing only the municipals participating in the study. To cross the data from the DMF averages by RHD with the digital cartographic base, the municipals were grouped by RHD. The two bases were connected through a common code or "primary key" - in other words, the name of each RHD [13]. This procedure was done in the TerraView ${ }^{\circledR}$ software program (version 4.2.1) [14]. The result of the crossing between the data from the digital cartographic base grouped by RHD and the data from the DMF averages is a series of thematic maps. To store the data, the polygon vector model was used [13-15].

In the thematic maps generated, the color gradient indicated areas with the lowest to highest averages, from the weakest to the strongest color. In addition, the classification of the legend was standardized into up to five extracts with intervals per quantis. A thematic map can generate different spatial standards, depending on the type of information to be inserted in the map legend [13].

\section{RESULTS}

The final sample was composed of 17,560 people examined in 163 municipals for the three age groups $(5,558$, 6,051 , and 5951 individuals, respectively, for the age groups 15-19 years, 35-44, and 65 and up). Most of the population studied reported a monthly household income between $\mathrm{R} \$ 501.00$ and $\mathrm{R} \$ 2,500.00$, with percentages of $75.07 \%$, $63.27 \%$, and $68.71 \%$ for the three age groups, respectively. For the number of years of study, most of the adolescents and adults reported over five years of study $(91.37 \%$ and $73.79 \%$, respectively), while the elderly were mostly in the range of one to five years of study. The percentage of illiterate people reported was $0.47 \%, 1.07 \%$, and $13.72 \%$, respectively, for the three groups. The data with the averages of the DMF components, separated by age group and RHD are presented in Table 1. We also highlight the presentation of the data regarding the average number of healthy subjects found in the population.

Figure 2 presents a map of the state of São Paulo grouped by the 17 RHDs with their respective municipals and with the DMF averages by age. The spatial distribution of the DMF averages was unequal (mosaic format) among the RHDs and age groups. The distribution of the DMF average for the adolescent population was the worst for RHD 8 (Franca), while RHDs 4 (Baixada Santista), 7 (Campinas), and 14 (São João da Boa Vista) presented lower averages. None of the RHDs presented a DMF average lower than 2 for the adolescent population. For the adult population, RHDs 4 (Baixada Santista) and 12 (Registro) presented the lowest DMF averages. On the other hand, RHDs 8 (Franca), 13 (Ribeirão Preto), and 16 (Sorocaba) demonstrated the worst results. In relation to the elderly population, RHD 4 (Baixada Santista) had the lowest average and RHD 9 (Marília) had the highest DMF average for this population.

Table 1. Data of the DMF components by RHD in the state of São Paulo, 2015.

\begin{tabular}{|c|c|c|c|c|c|c|c|c|c|c|c|c|}
\hline \multirow{2}{*}{ RHD } & \multicolumn{4}{|c|}{ Adolescent } & \multicolumn{4}{|c|}{ Adult } & \multicolumn{4}{|c|}{ Elderly } \\
\hline & Healthy & Carious & Extracted & Restored & Healthy & Carious & Extracted & Restored & Healthy & Carious & Extracted & Restored \\
\hline Grande São Paulo & 25.25 & 1.84 & 0.18 & 1.18 & 15.13 & 2.5 & 6.73 & 6.05 & 3.79 & 1.16 & 25.55 & 1.14 \\
\hline Araçatuba & 23.51 & 1.16 & 0.08 & 2.94 & 14.87 & 1.67 & 5.43 & 9.14 & 3.25 & 0.75 & 25.68 & 2.11 \\
\hline Araraquara & 24.58 & 1.35 & 0.2 & 2.15 & 14.43 & 1.72 & 6.12 & 7.89 & 2.76 & 0.47 & 26.43 & 1.57 \\
\hline Baixada Santista & 25.97 & 1.01 & 0.22 & 1.42 & 16.90 & 1.41 & 5.92 & 6.83 & 5.88 & 0.95 & 21.5 & 3.36 \\
\hline Barretos & 23.39 & 0.96 & 0.14 & 2.77 & 13.11 & 2.45 & 5.8 & 8.86 & 2.46 & 0.59 & 27.13 & 1.36 \\
\hline Bauru & 24.21 & 1.39 & 0.13 & 2.58 & 15.04 & 1.72 & 7.04 & 6.9 & 3.06 & 0.75 & 26.43 & 1.42 \\
\hline Campinas & 25.65 & 0.63 & 0.1 & 1.76 & 15.24 & 1.35 & 5.69 & 8.64 & 2.65 & 0.34 & 26.97 & 1.85 \\
\hline Franca & 22.32 & 2.87 & 0.15 & 2.55 & 13.38 & 2.5 & 6.43 & 8.68 & 2.77 & 0.91 & 26.59 & 1.42 \\
\hline Marília & 23.76 & 1.52 & 0.14 & 2.89 & 14.31 & 2.42 & 5.66 & 8.42 & 2.01 & 0.65 & 28.28 & 0.87 \\
\hline Piracicaba & 24.7 & 1.37 & 0.22 & 1.94 & 14.94 & 1.09 & 6.06 & 8.53 & 3.05 & 0.4 & 26.03 & 1.95 \\
\hline Presidente Prudente & 23.37 & 0.78 & 0.1 & 2.72 & 14.97 & 1.57 & 6.52 & 8.33 & 3.79 & 0.54 & 25.17 & 2.04 \\
\hline Registro & 24.37 & 2.14 & 0.17 & 1.62 & 16.99 & 3.61 & 5.33 & 5.04 & 3.54 & 0.96 & 26.3 & 0.91 \\
\hline Ribeirão Preto & 22.95 & 1.14 & 0.14 & 2.79 & 12.42 & 2.06 & 6.25 & 9.89 & 2.24 & 0.41 & 26.48 & 2.17 \\
\hline S. João da Boa Vista & 25.65 & 0.54 & 0.13 & 2.11 & 14.39 & 1.96 & 6.42 & 8.07 & 2.46 & 0.42 & 27.21 & 1.37 \\
\hline S. José do Rio Preto & 23.65 & 1.85 & 0.10 & 2.85 & 14.90 & 1.49 & 5.24 & 8.86 & 3.61 & 0.48 & 24.57 & 2.13 \\
\hline Sorocaba & 23.81 & 2.21 & 0.17 & 2.16 & 13.52 & 2.65 & 7.83 & 7.17 & 2.48 & 0.85 & 26.45 & 1.67 \\
\hline Taubaté & 24.3 & 1.31 & 0.15 & 1.95 & 14.65 & 1.75 & 5.89 & 8.71 & 3.26 & 0.72 & 25.78 & 1.91 \\
\hline
\end{tabular}




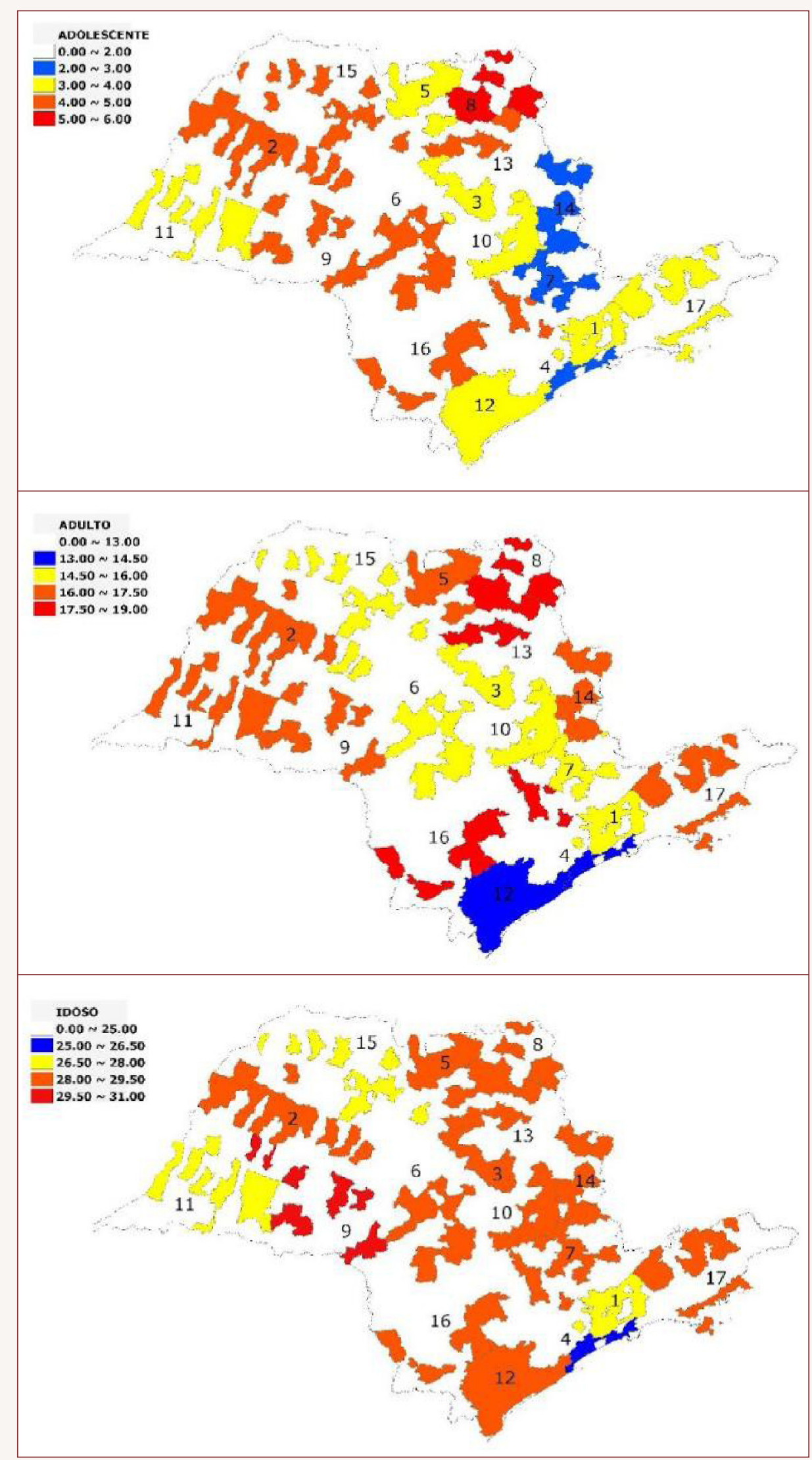

Figure 2. Mapping of the DMF index for the adolescent (15 to 19 years), adult (35 to 44 years), and elderly (65 years and up) age groups, according to the macro region and state of São Paulo. 


\section{DISCUSSION}

Due to the probabilistic sampling used in the methodology of SB SP 2015, the results of this study can be inferred for the population of the state of São Paulo. The spatial analysis undertaken showed the occurrence of areas where the extension of caries is significantly higher than others - a situation similar to that found in the Brazilian context in an epidemiological survey done in 2010 [16].

The areas with highest predominance of caries may be the result of households in society of people with high risk of caries. Paying attention to health issues with the objective of modifying them is the responsibility of public health managers, since both the risk and protection factors can impact the population unequally, contributing to an even higher increase in health inequalities $[5,7,17]$.

In Brazil, the different regional realities produce distinct modes of organization and management of health systems that impact the quality of access to and assistance for oral health, meaning that the universalization of this access depends on an environment or locoregional context favorable to its effectuation [6]. The most recent national survey held in 2010 exhibited a polarization of caries, where the disease burden is concentrated in a smaller vulnerable part of the population, thus exposing the importance of the Social Determinants of Health [18].

However, despite the importance of the data obtained by SB Brazil 2010 [18], the study showed a sample that did not allow more direct inference for the state of São Paulo (responsible for $25 \%$ of the Brazilian population) and, specifically, for its regions - information that managers require as a strategy inserted in the health surveillance component and that was arduously researched in this study, given the need for accurate data on the epidemiological reality of the state and territory.

The DMF index is used worldwide to evaluate the presence of caries and access to dental care. Its use demonstrates that caries are a global public health issue of complex and multifactorial development, strongly associated with the influence of demographical, socioeconomic, and behavioral factors [19]. Given the proportion of caries and their relation to negative repercussions for individuals and communities worldwide, the Global Oral Health Inequalities: Dental Caries Task Group synthesized the current evidence to develop a five-year agenda with the goal of researching and implementing improvements to global oral health, particularly integrated action to reduce caries and inequalities in health among and within countries with an epidemiological mapping of the total experience of clinical caries, aiming towards the recognition, monitoring, and control of inequalities on local and regional levels [5].

In this study, the worst DMF averages in the adolescent and adult populations for RHD 8 (Franca) may demonstrate the influence of socioeconomic and contextual factors on the DMF results of the region. On the other hand, the RHD 4 (Baixada Santista) presented lower DMF averages for the three population samples. Although not explicitly presented, socioeconomic disadvantages can lead to the distribution of disease [20].

In the adolescents, the prevalence of caries was moderate (3.57), although there were improvements to the indicators for the prevalence and percentage of people free of caries in relation to the data from the state survey in 2002 (6.4) and that for the Southeast region in SB Brazil 2010 (3.83) [16]. The percentage of people free from caries has risen from 2002 to 2015 (9.7-28.96\%).

Considering that primary health care presents limitations, especially when analyzing the percentages of adolescents requiring root canal fillings (4.20\%) and extractions (6.80\%), it becomes evident that managers must join efforts beyond primary health care [12], investing also in secondary health care with the objective of avoiding premature dental loss. In addition, early interventions are simpler and cheaper, and reduce the gravity of the cases and mutilations [20].

The planning of health interventions for the reduction of caries and their consequences in adolescents depends on recognizing that both individual and contextual factors are associated with the experience of caries in this age group. Therefore, by placing equity as a priority in planning health care actions, health care services must direct their additional resources to the areas and population segments with higher needs [21]. Based on the results found in this study, we suggest that managers turn their attention to the differences between regions to more adequately plan for the adolescent population.

Interventions for caries should be directed toward improving the quality of life of individuals and communities, as well as the sphere of health care services [22]. The worst conclusion to this disease is tooth loss, since tooth extraction is considered a result of its aggravation [22]. This study showed that a high number of tooth extractions still occur, with an indication of extraction in adults (6.30 and $17.26 \%$, respectively) [12]. In addition, a considerable percentage require root canal fillings $(6.31 \%)$, which shows the limitations of the services in primary and secondary care.

However, despite these negative results, this age group presented improvements, mainly when compared to the state survey of 2002, which can be explained by socioeconomic changes such as higher income per capita and better scholastic levels. These are associated with better access to dental services and oral hygiene products, with consequent improvement to the health profile of adults [23].

For the elderly age group, the data remained concerning, considering that most of them use total prostheses, over half of them have lost all of their teeth (in other words, they are totally toothless), few have healthy teeth, and a significant portion still require extractions [12]. Given this scenario, it is important to reflect on the cultural production of oral health in Brazil based on the resource of dental extraction. Historically, tooth extraction is seen as an acceptable resource for facing the realities of dental pain produced in the most diverse social contexts. Overcoming this situation requires ample secondary health care services that can guarantee access to endodontic treatment for all in 
order to cure pain [24], since the Dental Specialties Centers are capable of offering services that involve early diagnosis and immediate treatment, in addition to limiting damage and providing rehabilitation, consequently improving the health conditions of the population [25].

Considering the results found in this study, suggestions are proposed for municipal and state managers, with a few priorities for oral health actions in the state of São Paulo, namely: observation of the epidemiologic mapping presented in this study with the distribution of caries experience, prioritizing actions in the regions with the worst results; integration between the actions of promoting oral health and promoting general health; integration between the actions of promoting oral health and other sectors such as sanitation, to improve health and reduce inequalities of caries; actions for guaranteeing integral oral health care by improving references and counter references between primary and secondary health care; and prioritization of facilitation measures so that small municipals do not encounter barriers to guaranteeing their inhabitants access to secondary care.

\section{CONCLUSIONS}

We conclude that, despite the improvements to the DMF averages for adults and the elderly, caries remains a serious issue in public health, mainly for the elderly of the state of São Paulo. Lastly, the variances in the DMF averages among the RHDs and among the populations studied demonstrate the need for planning different locoregional oral health actions to treat the severe clinical state exposed, since its spatial distribution is disparate, with concentrations of cases in certain regions for all age groups studied.

\section{ACKNOWLEDGMENTS}

The authors thank to Espaço da Escrita - Coordenadoria Geral da Universidade - UNICAMP - for the language services provided.

Financial support: FAPESP (\# 14/50109-1), SES-SP, CNPq and FAEPEX (\# 0966/15)

\section{REFERENCES}

1. Pereira AC. Tratado de Saúde Coletiva em Odontologia. Nova Odessa: Napoleão; 2009. $704 \mathrm{p}$

2. Soares CLM, Paim JS. Aspectos críticos para a implementação da política de saúde bucal no Município de Salvador, Bahia, Brasil. Cad Saude Publica. 2011;27(5):966-74. https://doi.org/10.1590/S0102$311 \times 2011000500014$

3. Brasil. Ministério da Saude S de A à SD de AB. Projeto SB Brasil 2003: condições de saúde bucal da população brasileira 2002-2003: resultados principais. Série C Projetos Programas e Relatórios. 2004. 68 p.

4. Pucca Jr GA. A política nacional de saúde bucal como demanda social. Cien Saude Colet 2006;11(1):243-6. https://doi.org/10.1590/S141381232006000100033

5. Pitts NB, Amaechi B, Niederman R, Acevedo AM, Vianna R, Ganss C, et al. Global Oral Health Inequalities:Dental Caries Task GroupRsearch Agenda. Adv Dent Res 2011;23(2):211-20. https://doi. org/10.1177/0022034511402016

6. Peres KG, Peres MA, Boing AF, Bertoldi AD, Bastos JL, Barros AJD. Redução das desigualdades sociais na utilização de serviços odontológicos no
Brasil entre 1998 e 2008. Rev Saude Publica 2012;46(2):250-8. https:// doi.org/10.1590/S0034-89102012000200007

7. Boing AF, Bastos JL, Peres KG, Antunes JLF, Peres MA. Social determinants of health and dental caries in Brazil: a systematic review of the literature between 1999 and 2010. Rev Bras Epidemiol 2014;17(2):102-15. https:// doi.org/10.1590/1809-4503201400060009

8. Moreira R da S, Nico LS, Tomita NE. A relação entre o espaço e a saúde bucal coletiva: por uma epidemiologia georreferenciada. Cien Saude Colet 2007;12(1):275-84. https://doi.org/10.1590/S1413-81232007000100031

9. Pereira SM, Ambrosano GMB, Cortellazzi KL, Tagliaferro EPS, Vettorazzi CA, Ferraz SFB, et al. Geographic information systems (GIS) in assessing dental health. Int J Env Res Public Heal 2010;7(5):2423-36. https://doi. org/10.3390/ijerph7052423

10. Silva NN. Amostragem probabilística. 3a. EDUSP, editor. São Paulo; 1998. $1998 \mathrm{p}$.

11. Who. Oral Health Surveys - Basic Methofd. World Heal Organ 2013;1.137

12. Pereira AC, Frias AC, Vieira V. Pesquisa estadual de saúde bucal: relatório final. 1a. Vol. 1. Águas de São Pedro: Livronovo; 2016

13. Brasil. Ministério da Saúde. Secretaria de Vigilância em Saúde. Fundação Oswaldo Cruz. Abordagens espaciais na saúde pública [Internet]. Ministério da Saúde, editor. Abordagens Espaciais na Saúde Pública. Brasília; 2006. 136 p. Available from: http://bvsms.saude.gov.br/bvs/ publicacoes/serie geoproc vol 1.pdf

14. Instituto Brasileiro de Geografia e estatística. Bases Cartográficas do Brasil [Internet]. 2017 [cited 2017 Dec 4]. http://www.ibge.gov.br/home/ estatistica/populacao/. Available from: https://ww2.ibge.gov.br/home/ geociencias/cartografia/default.shtm

15. Werneck GL. Georeferenced data in epidemiologic research. Cien Saude Colet 2008;13(6):1753-66. https://doi.org/10.1590/S141381232008000600010

16. Brasil. Ministério da Saúde. Resultados Principais SB Brasil 2010 [Internet]. Brasília - DF. 2011. Available from: http://189.28.128.100/dab/ docs/geral/projeto_sb2010_relatorio_final.pdf

17. Antunes JLF, Narvai PC. Políticas de saúde bucal no Brasil e seu impacto sobre as desigualdades em saúde. Rev Saude Publica 2006 Dec;44(2):360-5. https://doi.org/10.1590/S0034-89102010000200018

18. Brasil, Brasil. Ministério da Saúde. Secretaria de Atenção à Saúde Secretaria de Vigilância em Saúde. SB Brasil 2010: Pesquisa Nacional de Saúde Bucal: resultados principais. 2012. 116 p.

19. Shaffer J, Polk D, Feingold E, Wang X, Cuenco K, Weeks D, et al Demographic, socioeconomic, and behavioral factors affecting patterns of tooth decay in the permanent dentition: principal components and factor analyses. Community Dent Oral Epidemiol 2013;41(4):364-73. https://doi org/10.1111/cdoe.12016

20. Rocha CM, Kruger E, Whyman R, Tennant M. Predicting geographically distributed adult dental decay in the greater Auckland region of New Zealand. Community Dent Health 2014 Jun;31(2):85-90

21. Frias AC, Antunes JLF, Junqueira SR, Narvai PC. Determinantes individuais e contextuais da prevalência de cárie dentária não tratada no Brasil. Rev Panam Salud Publica 2007;22(4):279-85. https://doi.org/10.1590/S102049892007000900008

22. Baldani MH, Vasconcelos AGG, Antunes JLF. Associação do índice CPO-D com indicadore s sócio-econômicos e de provisão de serviços odontológicos no Estado do Paraná , Brasil. 2004;20(1):143-52.

23. Nascimento $S$ do, Frazão $P$, Bousquat $A$, Antunes JLF. Condições dentárias entre adultos brasileiros de 1986 a 2010. Rev Saude Publica 2013 Dec;47(suppl 3):69-77. https://doi.org/10.1590/S00348910.2013047004288

24. Costa SDM, Vasconcelos M, Verdi M. Desigualdades na distribuição da cárie dentária no Brasil: uma abordagem bioética. Cien Saude Colet 2013;18(2):461-70. https://doi.org/10.1590/S1413-81232013000200017

25. Goes PSA De, Figueiredo N, Neves JC Das, Silveira FMDM, Costa JFR, Pucca Júnior GA, et al. Avaliação da atenção secundária em saúde bucal: uma investigação nos centros de especialidades do Brasil Cad Saude Publica. 2012;28:s81-9. https://doi.org/10.1590/S0102$311 \times 2012001300009$ 